\title{
PENGAMALAN BUTIR PANCASILA: PERWUJUDAN IMPLEMENTASI PANCASILA SEBAGAI ETIKA DALAM HIDUP BERMASAYARAKAT
}

\author{
Leni Yulia \& Dinie Anggraeni Dewi \\ Universitas Pendidikan Indonesia \\ yulialeni@upi.edu
}

\begin{abstract}
Abstrak
Sejarah telah mengungkapkan bahwa Pancasila adalah jiwa dan jati diri manusia Indonesia yang menjadi kekuatan, pedoman, sumber hukum serta pembimbing arah dalam menjalankan kehidupan bermasyarakat. Dengan makna serta nilai-nilai yang terkandung dalam pancasila yang menjadi tuntunan agar senantiasa menjalan kehidupan bermasyarakat berlandaskan nilai-nilai butir pancasila. Nilai makna yang sedemikan melekat dengan etika hidup manusia indonesia menjadi sistem kesatuan yang tidak dapat dipisahkan. Hal itu mewujudkan bahwa implementasi nilai Pancasila senantiasa terwujud dan terlaksana dalam hidup serta sanubari manusia indonesia. Pengamalan nilai butir Pancasila yang menjadi perwujudan implementasi mendorong terwujudnya manusia indonesia menjadi semakin berjiwa dan berjati diri berlandaskan Pancasila.
\end{abstract}

Kata kunci: Pancasila, Etika, Implementasi

\begin{abstract}
History has revealed that Pancasila is the soul and identity of Indonesian people who become the strength, guidance, source of law and guide for the direction in carrying out social life. With the meaning and values contained in Pancasila which are the guidance to always live a community life based on the values of the Pancasila points. The value ofmeaning that is inherent in the ethics of Indonesian human life becomes an inseparable system of unity. This realizes that the implementation of Pancasila values is always materialized and carried out in the life and heart of Indonesian people. The practice of the value of the Pancasila point which is the embodiment of implementation encourages the realization of Indonesian people to become more spirited and have an identity based on Pancasila.
\end{abstract}

Keywords: Pancasila, Ethics, Implementation

\section{PENDAHULUAN}

Dalam menjalankan kehidupan bermasyarakat kita sebagai warga negara yang memiliki pedoman dan pandangan hidup tentu mengetahui bahwa pancasila adalah pedoman sekaligus merupakan pandangan hidup berbangsa dan bernegara. Sejarah yang bersertakan perjuangan bangsa dalam mencapai kemerdekaan telah menghantarkan rakyat indonesia kepada Negara Republik Indonesia yang merdeka, bersatu, berdaulat berdasarkan pancasila. Maka hal ini sudah menjadi tugas dan tanggung jawab kita sebagai warga negara untuk mengemban kelangsungan hidup serta mewujudkan nilai-nilai yang terkandung dalam pancasila (Nurgiansah, 2021b).

Nilai-nilai yang terkandung di dalam sila-sila Pancasila merupakan cita-cita, harapan, dambaan bangsa Indonesia yang akan diwujudkan dalam kehidupannya. Nilai-nilai yang terkandung dalam Pancasila itu memiliki tingkatan dan bobot yang berbeda, namun tidak saling bertentangan. Pancsila merupakan substansi utuh atau kesatuan organik (Kaelan:2013).

Telah diungkapkan bahwa pancasila adalah jiwa, jati diri seluruh warga negara indonesia, yang memberikan kekuatan dan dorongan hidup kepada bangsa serta membimbing dan mengajarkan kehidupan lahir dan batin yang semakin membaik didalam masyarakat indonesia yang adil makmur (Dewantara, Hermawan, et al., 2021).

Pancasila yang menjadi pandangan 
serta pedoman hidup adalah acuan yang sekaligus menjadi arah kita sebagai warga negara yang hidup dengan berdasarkan dasar negara kita yaitu pancasila. Nilainilai yang terkandung dalam pancasila adalah pedoman kita dalam hidup berbangsa serta menjadi asa- asa dalam bertindak atau berperilaku kita dalam hidup. Tujuan disusunnya pancasila yang dimana disusun atau dirumuskan bukan semata- mata hanya untuk adanya dasar negara, tetapi pancasila dirumuskan sebagaimana berdasarkan karater jiwa bangsa indonesia yang berasaskan lima sila dalam pancasila (Nurgiansah, 2021a).

Para pendiri negara merumuskan pancasila dengan sedemikiannya agar senantiasa warga negara indonesia hidup berdasarkan pancasila hingga terwujudnya cita- cita bangsa yang tercantum dalam Pembukaan UUD Tahun 1945 alinea IV yaitu "melindungi segenap bangsa Indonesia dan seluruh tumpah darah Indonesia, memajukan kesejahteraan umum, mencerdaskan kehidupan bangsa, dan ikut melaksanakan ketertiban dunia yang berdasarkan kemerdekaan perdamaian abadi dan keadilan sosial".

Menyadari hal itu maka untuk mewujudkannya perlu ada usaha sadar dan nyata yang berdasarkan nilai-nilai pancasila sehingga terwujudnya suatu citacita bangsa indonesia serta terbentuknya warga negara yang mengimplementasikan nilai-nilai pancasila dalam hidup hidup bermasyarakat akan mendorong terwujudnya cita-cita bangsa, serta seluruh masyarakat Indonesia yang berjiwakan pancasila melekat dengan nilai-nilai moral, taat hukum, beretika dan menjungung tinggi persatuan dan kesatuan bangsa.

\section{METODE PENELITIAN}

Metode penelitian menggunakan studi kepustakaan dengan sumber pengumpulan data melalui literatur jurnal ilmiah yang diterbitkan di jurnal nasional yang terakreditasi.

\section{HASIL PENELITIAN DAN PEMBAHASAN Hasil Penelitian}

Pengetian pancasila dilihat dari tiga sudut pandang yaitu secara Etimologis, historis, dan Terminologis. Secara etimologis, yaitu bahwa Pancasila berasal dari bahasa Sanskerta. Panca artinya lima (5), sedangkan sila artinya dasar, sendi, atau unsur. Jadi, Pancasila mengandung arti lima dasar, lima sendi, atau lima unsur. Istilah Pancasila awalnya terdapat dalam teks kepustakaan Buddha di India. Ajaran Buddha bersumber pada kitab suci Tri Pitaka, yang terdiri atas tiga macam buku besar yaitu Suttha Pitaka, Abhidama Pitaka, dan Vinaya Pitaka.

Di dalam ajaran Buddha terdapat ajaran moral untuk mencapai nirvana melalui Samadhi, dan setiap golongan berbeda kewajiban moralnya. Ajaranajaran moral tersebut antara lain Dasasila, Saptasila, dan Pancasila (Asep Sulaiman 2015:19). Istilah pancasila yang diambil dari kepustakaan tersebut memiliki arti secara sederhana yang artinya lima aturan dan larangan. Pada proses perumusan pancasila diawali pada sidang BPUPKI (Badan Penyidik Usaha Persiapan Kemerdekaan Indonesia) yang mana hasil dari sidang itu diantaranya pada tanggal 29 Mei tahun 1945, Mr. Mohc.Yamin berpidato tentang dasar negara. Beliau mengemukakan pemikirannya tentang dasar negara di hadapan peserta BPUPKI lengkap dengan Badan Penyelidik. Pidato Mr. Muhammad Yamin itu berisikan lima asas dasar negara Indonesia merdeka yang diidam-idamkan yaitu :1) Peri Kebangsaan, 2) Peri Kemanusiaan, 3) Peri Ketuhanan, 4) Peri Kerakyatan, dan 5) Kesejahteraan Rakyat.

Setelah berpidato, beliau juga menyampaikan usul tertulis mengenai rancangan UUD Republik Indonesia. Di dalam Pembukaan dari rancangan UUD tersebut, tercantum rumusan lima asas 
dasar negara yang rumusannya yaitu: 1) Ketuhanan Yang Maha esa, 2)Kebangsaan Persatuan Indonesia, 3) Rasa Kemanusiaan yang Adil dan Beradab, 4) Kerakyatan yang Dipimpin oleh Hikmat Kebijaksanaan dalam Permusyawaratan Perwakilan, dan 5) Keadilan Sosial bagi Seluruh Rakyat Indonesia. Pada tanggal 1 Juni 1945 Soekarno menyampaikan pidatonya di hadapan Badan Penyelidik. Dalam pidato tersebut, Soekarno secara lisan mengusulkan lima asas dasar negara Indonesia yang akan dibentuknya, yang rumusannya yaitu :1) Nasionalisme atau Kebangsaan Indonesia,

Internasionalisme atau Perikemanusiaan, 3) Mufakat atau Demokrasi, 4) Kesejahteraan Sosial, 5) Bertakwa kepada Tuhan Yang Maha Esa. Selanjutnya, beliau mengusulkan bahwa kelima sila tersebut dapat diperas menjadi "Tri Sila" yang rumusannya: 1) Sosio Nasional yaitu "Nasionalisme dan Internasionalisme"; 2) Sosio Demokrasi yaitu "Demokrasi dengan Kesejahteraan Rakyat"; 3) Ketuhanan Yang Maha esa. Adapun "Tri Sila" tersebut masih bisa diperas lagi menjadi "Eka Sila" atau satu sila yang intinya adalah "gotongroyong". Pada tahun 1947, pidato bersejarah Ir. Soekarno tersebut diterbitkan dan dipublikasikan dengan diberi judul "Lahirnya Pancasila",

sehingga negara menetapkan bahwa tanggal 1 Juni merupakan hari lahirnya Pancasila. Pada tanggal 22 Juni 1945, sembilan tokoh nasional yang juga tokoh Dokuritzu Zyunbi Toosakay mengadakan pertemuan untuk membahas pidato serta usulan mengenai dasar negara yang telah dikemukakan dalam sidang BPUPKI sebagai Badan Penyelidik. Sembilan tokoh tersebut dikenal dengan "Panitia Sembilan", yang setelah mengadakan sidang berhasil menyusun sebuah naskah piagam yang dikenal "Piagam Jakarta", yang di dalamnya memuat Pancasila, sebagai hasil yang pertama kali disepakati oleh negara. Adapun rumusan Pancasila sebagaimana termuat dalam "Piagam Jakarta" yaitu : 1) Ketuhanan dengan kewajiban menjalankan syariat Islam bagi pemelukpemeluknya, 2) Kemanusiaan yang adil dan beradab, 3) Persatuan Indonesia, 4) Kerakyatan yang dipimpin oleh hikmat kebijaksanaan dalam permusyawaratan perwakilan, 5) Keadilan negara bagi seluruh rakyat Indonesia.

Proklamasi Kemerdekaan pada tanggal 17 Agustus tahun 1945 itu telah melahirkan Negara Republik Indonesia. Untuk melengkapi alat-alat perlengkapan negara sebagaimana lazimnya negara yang merdeka, Panitia Persiapan Kemerdekaan Indonesia (PPKI) segera mengadakan rumusan dasar negara. Maka PPKI dalam sidangnya tanggal 18 Agustus 1945 telah berhasil mengesahkan UUD Negara Republik Indonesia yang dikenal dengan UUD 1945. Adapun UUD 1945 tersebut terdiri atas dua bagian, yaitu Pembukaan UUD 1945 dan pasal-pasal UUD 1945 yang berisi 37 pasal, 1 Aturan Peralihan yang terdiri atas 4 pasal, dan 1 Aturan Tambahan yang terdiri atas 2 ayat.

\section{Pembahasan}

Pancasila sebagai dasar negara yaitu merupakan bahwa pada pembukaan UUD Tahun 1945 membuat dasar negara pancasila yang termuat dalam alinea ke empat yang berbunyi "maka disusunlah kemerdekaan kebangsaan itu dalam suatu Undang-Undang Dasar Negara Indonesia yang terbentuk dalam susunan Negara Republik Indonesia yang berkedaulatan rakyat dengan berdasarkan ketuhanan yang maha esa, kemanusiaan yang adil dan beradab, perstuan Indonesian dan kerakyatan yang dipimpin oleh kebijaksaan dalam permusyawaratan/perwakilan..”. Lahirnya Pancasila sebagai dasar negara merupakan suatu kebutuhan sosial, historis dan politik yang sangat mendasari terbentuknya identitas serta penegasnya 
jati diri bangsa indonesia (Iriyanto, dkk :2007). Makna sebagai dasar negara yaitu bahwa pencasila merupakan landasan penyelenggaran negara serta pelaksanaan sistem pemerintah yang mempunyai kedudukan tertinggi dan sebagai sumber dari segala sumber hukum dalam ketata negaraan di Indonesia, konsekuensinya dalam segala peraturan yang ada harus berdasarkan dan bersumberkan dari pancasila.

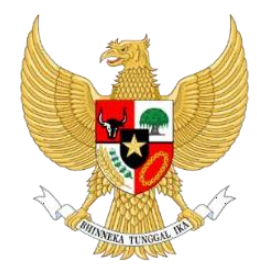

(Sumber:https://id.wikipedia.org/wiki/Berk as:National_emblem_of_Indonesia_Garuda_P ancasila.svg)

Sebagai dasar negara pancasila merupakan pokok kaidah negara yang fundamental, sebagai asas negara yang menjiwai dan memiliki kedudukan istimewa dalam hidup kenegaraan dan hukum bangsa indonesia. Pokok kaidah yang fundamental adalah norma hukum pokok yang bagi negara yang dalam hukum mempunyai kedudukan yang tetap, kuat, dan tidak bisa diubah bagi negara yang dibentuk. Pancasila mempunyai sifat yang imperatif atau mengikat, yang artinya negara dengan setiap warga negara harus mematuhi dan taat padanya.

Mengenai pancasila sebagai pandangan hidup bangsa merupakan pedoman serta arah dan petunjuk hidup dalam berpikir, bertindak bagi masyarakat bangsa indonesia dalam kehidupan seharihari. Hal ini pancasila sebagai pandangan hidup bangsa senantiasa mewujudkan masyarakat yang cerdas serta melekatnya nilai, norma-norma yang tersirat pada nilai pancasila sehingga terwujudnya cita-cita bangsa.
Dalam Kamus Besar Bahasa Indonesia etika adalah ilmu apa yang baik dan yang buruk, hak dan kewajiban moral (moral). Ini dapat diartikan bahwa etika merupakan asas kumpulan nilai yang berkenaan dengan akhlak baik itu yang yang benar ataupun salah. Istilah "etika" berasal dari bahasa Yunani, "Ethos" yang artinya tempat tinggal yang biasa, padang rumput, kandang, kebiasaan, adat, watak, perasaan, sikap, dan cara berpikir. Secara etimologis, etika berarti ilmu tentang segala sesuatu yang biasa dilakukan atau ilmu tentang adat kebiasaan. Dalam arti ini, etika berkaitan dengan kebiasaan hidup yang baik, tata cara hidup yang baik, baik pada diri seseorang maupun masyarakat.

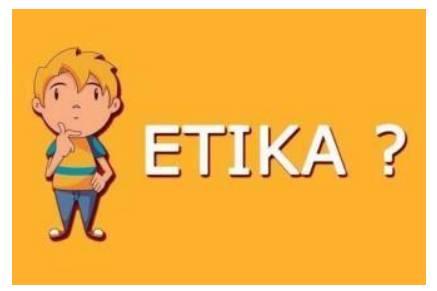

\section{(Sumber:https://sepositif.com/pengertian- etika-adalah-ciri-ciri-jenis-dan-contoh etika/)}

Etika dimengerti secara umum adalah perilaku manusia yang berkenaan dengan sopan santun, moral, etitud serta budi yang luhur, namu hal yang bertolak belakang dari hal itu merupakan etika yang kurang baik. Etika berkaitan dengan hidup seseorang baik dalam tata cara hidup, kebiasaan hidup atau bagaimana seseorang itu menjalani hidupnya. Kebiasaan yang baik dapat diwariskan pada generasigenerasi yang akan datang, sehingga dalam arti etika sama maknanya dengan moral.

Perilaku yang mencerminkan seseorang beretika baik sering kita jumpai atau bahkan kita lakukan dalam kehidupan sehari-hari. Seperti halnya seseorang yang memberi salam kepada siapapun dan dalam melakukan apapun diawali dengan salam. Menghormati orang yang usianya 
dan bertutur kata yang sopan. Sikap atau perilaku yang mengacu kepada nilai- nilai yang terkandung dalam Pancasila, maka Pancasila dapat menjadi sistem etika yang sangat kuat dan bisa mewujudkan dengan pengamalan nilai Pancasila dalam hidup ermasyarakat, nilai-nilai yang ada tidak hanya bersifat mendasar, tetapi juga realistis dan aplikatif (Sri Rahayu:2008)

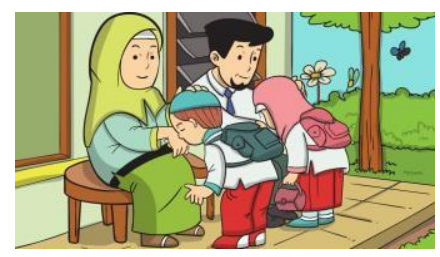

(Sumber:https://smpn1baturetno.sch.id/eti ka-terhadap-guru/)

Etika Pancasila adalah cabang filsafat yang merupakan penjabarkan dari sila-sila Pancasila untuk mengatur perilaku kehidupan bermasyarakat, berbangsa, dan bernegara di Indonesia. Maka dalam etika Pancasila terkandung nilai-nilai ketuhanan, kemanusiaan, persatuan, kerakyatan, dan keadilan. Kelima nilai tersebut membentuk perilaku manusia Indonesia dalam semua aspek kehidupannya.

Sila ketuhanan mengandung nilai moral berupa nilai spiritualitas yang mendekatkan diri manusia kepada Sang Pencipta, ketaatan kepada nilai agama yang dianutnya. Sila kemanusiaan mengandung dimensi humanus atau kemanusiaan, artinya memanusiakan manusia lebih manusiawi, yaitu upaya meningkatkan kualitas kemanusiaan dalam pergaulan anta rsesama. Sila persatuan mengandung dimensi nilai solidaritas, rasa kebersamaan cinta tanah air. Sila kerakyatan mengandung dimensi nilai berupa sikap menghargai orang lain, mau mendengar pendapat orang lain, tidak memaksakan kehendak kepada orang lain. Sila keadilan mengandung dimensi nilai mau peduli atas nasib orang lain, kesediaan membantu kesulitan orang lain. Sehingga etika Pancasila itu lebih dekat pada pengertian etika keutamaan atau etika kebajikan.

Pengamalan nilai-nilai Pancasila dalam hal pengelolaan lingkungan hidup atau bermasyarakat merupakan kesatuan yang bulat dan utuh yang memberikan keyakinan kepada rakyat dan bangsa Indonesia, bahwa kebahagiaan hidup akan tercapai jika didasarkan atas keselarasan, keserasian dan keseimbangan, baik dalam hubungan manusia dengan Tuhan Yang Maha Esa maupun manusia dengan manusia; manusia dengan alam dan manusia sebagai pribadi, dalam rangka mencapai kemajuan lahir dan kebahagiaan batin. (Koesnadi Hardjasoemantri, 2000 : 575). Sebagaimana dari uraian di atas, mengenai makna pancasila sebagai pandangan dan pedoman hidup bangsa berserta etika pancasila, maka pengamalan butir pancasila sebagai wujud implementasi pancasila sebagai sistem etika dalam hidup bermasyarakat akan diuraikan berdasarkan sila-sila pancasila sebagai berikut :

\section{Sila Ketuhanan Yang Mahas Esa}

Sila Ketuhanan Yang Maha esa ini nilai-nilainya meliputi dan menjiwai keempat sila lainnya. Dengan sila ini bangsa indonesia menyatakan bahwa kepercayaan dan ketakwaan terhadap Tuhan Yang Maha Esa dan oleh karenanya masyarakat indonesia percaya dan bertakwa kepada Tuhan Maha Esa sesuai dengan agama dan kerpcayaan yang dianut oleh seluruh masyarkat. Dalam sila Ketuhanan Yang Maha esa terkandung nilai bahwa negara yang didirikan merupakan pengejawantahan tujuan manusia sebagai makhluk Tuhan Yang Maha esa.(Asep Sulaiman 2015:45) 


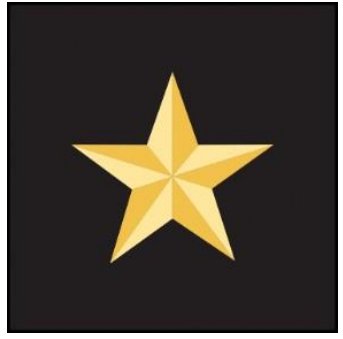

(Sumber:https://www.goodnewsfromindo nesia.id/2020/06/23/)

Menyadari bahwa agama dan kepercayaan terhadap Tuhan Yang Maha Esa merupakan masalah yang menyakut hubungan pribadi sendiri dengan Tuhan, maka perlu dikembangkan sikap saling menghormati, menghargai serta bertoleransi dalam kebebasan menjalankan ibadah sesuai dengan agama yang dianutnya dan tidak memaksakan seseorang untuk menganut agama lainnya.

Oleh karena itu, segala hal yang berkaitan dengan kehidupan bermasyarakat baik dalam pelaksanaan dan penyelenggaraan negara bahkan moral negara, moral penyelenggara negara, politik negara, pemerintahan negara, hukum dan peraturan perundangundangan negara, kebebasan dan hak asasi warga negara, harus dijiwai nilai-nilai Ketuhanan Yang Maha esa. Maka implementasi nilai pancasila sila ketuhanan akan terwujud.

\section{Sila Kemanusiaan Yang Adil dan Beradab}

Dengan Sila Kemanusiaan yang Adil dan Beradab manusia diakui dan diperlakukan sesuai dengan harkat dan martabatnya sebagai makhluk Tuhan Yang Maha Esa yang sama derajatnya, hak dan kewajibannya yang sama tanpa membedamembedakan suku, ras, agama, dudukan sosial warna kulit dan sebagainya.

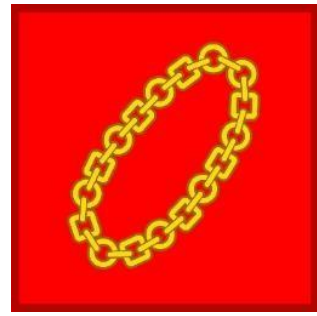

(Sumber:https://id.m.wikipedia.org/wiki/Be rkas:Pa ncasila_Sila_2_Chain.svg)

Kemanusiaan yang adil dan beradab menjungjung tinggi nilai kemanusiaan, gemar melakukan kegiatan kemanusiaan, dan berani membela keadilan dan kebenaran. Menyadari bahwa manusia adalah derajatnya sama, maka bangsa indonesia sebagai bagian dari seluruh umat manusia harus mengembangkan sikap saling menghormati dan bekerjasama. Sila kemanusiaan yang adil dan beradab merupakan dasar fundamental dalam kehidupan kenegaraan, kebangsaan, dan kemasyarakatan.

Nilai kemanusiaan ini bersumber pada dasar filosofis antropologis bahwa hakikat manusia adalah susunan kodrat rohani (jiwa) dan raga, sifat kodrat individu dan makhluk sosial, kedudukan kodrat makhluk pribadi berdiri sendiri, dan sebagai makhluk Tuhan Yang Maha esa.(Asep Sulaiman 2015:45)

\section{Persatuan Indonesia}

Sesuai dengan yang dicetuskan oleh Ir. Soekarno yang mengatakan bahwa prinsip negara adalah gotong royong, Ir.Soekarno mengatakan bahwa tidak boleh ada lagi klaim-klaim diantara golongan, pribadi, dan kelompok apapun yang hendak memperjuangkan kepentingan mereka sendiri di atas kepentingan bersama (Agutinus:2015). Artinya, tidak boleh ada klaim mayoritas atas minoritas. Tidak boleh ada klaim warga pribumi atas peranakan.Tidak boleh ada klaim kaum kaya atas kaum miskin. 
Sila Persatuan Indonesia tidak dapat dipisahkan dengan keempat sila lainnya karena seluruh sila merupakan suatu kesatuan yang bersifat sistematis.Dengan sila ini manusia Indonesia menempatkan persatuan dan kesatuan serta kepentingan dan keselamatan Bangsa dan Negara diatas kepentingan pribadi dan golongan. Artinya manusia indonesia sanggup dan rela berkorban untuk kepentingan bersama.

Oleh karena sikap rela berkorban yang berlandaskan cinta tanah air maka kembangkan rasa kebanggaan berkebangsaan dan bertanah air dalam rangka menertibkan dan memelihara perdamaian. Persatuan ini dikembangkan dengan atas dasar Bhinneka Tunggal Ika. Negara merupakan suatu persekutuan hidup bersama di antara elemen-elemen yang membentuk negara, yang berupa suku, ras, kelompok, golongan maupun kelompok agama. Oleh karena itu, perbedaan merupakan bawaan kodrat manusia dan merupakan ciri khas elemenelemen yang membentuk negara.

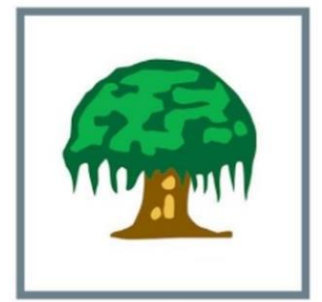

(Sumber:https://www.kompas.com/skola/i mage/)

Konsekuensinya, negara adalah beraneka ragam tetapi satu, mengikatkan diri dalam suatu persatuan yang dilukiskan dalam suatu seloka Bhinneka Tunggal Ika. Perbedaan bukannya untuk diruncingkan menjadi konflik dan permusuhan melainkan diarahkan pada suatu sintesis yang saling menguntungkan yaitu persatuan dalam kehidupan bersama untuk mewujudkan tujuan bersama.

Nilai persatuan Indonesia didasari dan dijiwai oleh sila Ketuhanan Yang Maha esa dan Kemanusiaan yang Adil dan Beradab. Hal ini terkandung nilai bahwa nasionalisme Indonesia adalah nasionalisme religius; yaitu nasionalisme yang bermoral Ketuhanan Yang Maha esa dan nasionalisme yang humanistik, yang menjunjung tinggi harkat dan martabat manusia sebagai makhluk Tuhan.

Oleh karena itu, nilai-nilai nasionalisme ini harus tercermin dalam segala aspek penyelenggaraan negara termasuk dalam era reformasi dewasa ini. Proses reformasi tanpa mendasarkan pada moral Ketuhanan, Kemanusiaan dan memegang teguh persatuan dan kesatuan, maka bukan tidak mungkin akan membawa kehancuran bagi bangsa Indonesia seperti halnya telah terbukti pada bangsa lain misalnya Yugoslavia, Srilangka, dan sebagainya (Asep Sulaiman 2015:47).

\section{Kerakyatan yang Dipimpin oleh Hikmat Kebijaksanaan dalam Permusyawara- tan /Perwakilan}

Nilai yang terkandung dalam sila Kerakyatan yang Dipimpin oleh Hikmat kebijaksaaan dalam Permusyawaratan/Perwakilan. Manusia indonesia mempunyai kedudukan, hak dan Kewajiban yang sama. Dalam menjalakan ataupun menggunakan haknya manusia indonesia menyadari bahwa perlunya selalu memperhatikan kepentingan dan mengutamakan kepentingan negara dan masyarakat. Hal ini pada dasarnya tidak boleh ada suatu kehendak yang dilaksanakan kepada pihak lain.

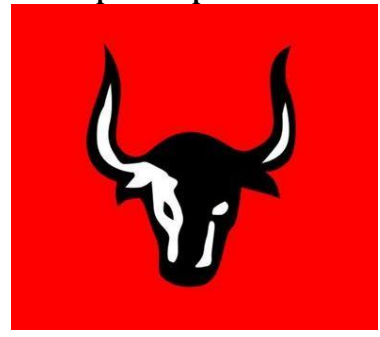

(Sumberhttps://kids.grid.id/read/47230103 9/) 
Manusia indonesia menghormati serta menjunjung tinggi setiap keputusan musyawarah, karena itu semua pihak yang bersangkutan harus menerimanya dan melaksanakannya dengan itikad baik dan dengan rasa tanggung jawab. Hal yang utama di sini adalah kepentingan bersama yang diatas atas kepentingan pribadi dan golongan (Dewantara \& Nurgiansah, 2021).

Hakikat rakyat merupakan sekelompok manusia sebagai makhluk Tuhan yang Maha esa, yang bersatu yang bertujuan mewujudkan harkat dan martabat manusia dalam suatu wilayah negara. Rakyat merupakan subjek pendukung pokok negara. Negara adalah dari, oleh, dan untuk rakyat (Dewantara, Nurgiansah, et al., 2021).

\section{Keadilan Sosial bagi Seluruh Rakyat Indonesia}

Dengan nilai yang terkandung dalam sila Keadilan Sosial bagi Seluruh Rakyat Indonesia manusia indonesia menyadari hak dan kewajiban yang sama dalam mewujudkan keadilan sosial dalam kehidupan. Hal ini perlu dikembangan perbuatan yang luhur yang mencerminkan sikap kekeluargaan dan gotong royong.

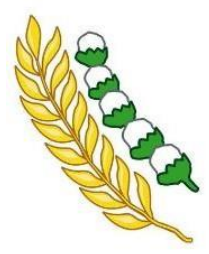

Sumber:https://batam.tribunnews.com/202 0/10/2 2/makna-sila-ke-5-pancasila-danpenerapannya-dalam-kehidupan-seharihari

Untuk itu perlu juga dikembangan sikap adil terhadap sesama, menjaga keseimbangan antara hak dan kewajiban serta menghormati hak orang lain. Demikian pula memupuk sikap suka memberi pertolongan kepada sesama dan kepada orang yang memerlukan agar dapat berdiri sendiri. Sikap suka bekerja keras dan sikap menghargai hasil karya orang lain yang bermanfaat untuk mencapai kemajuan dan kesejahteraan bersama. Semua itu dalam satu wadah yaitu dalam melaksanakan dan mewujudkan kemajuan yang rata dan keadilan sosial.

\section{Pengamalan Butir Pancasila Wujud Implementasi Pancasila Sebagai Sistem Etika}

Seperti yang kita ketahui sistem adalah suatu kesatuan yang terdiri dari komponen atau elemen yang dihubungkan bersama untuk memudahkan aliran informasi, materi atau energi untuk mencapai suatu tujuan. Sistem nilai dalam pancasila adalah satu kesatuan nilai-nilai yang ada dalam pamcasila yang saling berkaitan satu sama lain, tidak dapat dipisahkan ataupun ditukar tempatkan karena saling berkaitan antara satu dengan yang lain (Nurgiansah \& Widyastuti, 2020).

Wujud implementasi pancasila dalam etika merupakan pelaksanaan dari setiap makna dan nilai yang terkandung dalam setiap sila-sila pancasila dituangkan dan dilaksanakan dalam kehidupan bermasyarakat dan bernegara. Pancasila sumber nilai memunyai sifat yang refomatif, artinya memiliki aspek pelaksanaan dan perwujudan yang senantiasa menyesuaikan dengan dinamika aspirasi rakyat (Achmad Muchji:2007). Etika pancasila dilaksanakan dengan berpedoman pada nilai pancasila dan wujudkan dalam kehidupan.

Pancasila dalam aspek pembangunan berwawasan lingkungan tidak bisa dipisahkan, Pancasila yang merupakan kesatuan dan persatuan yang bulat dan utuh yang memberikan keyakinan kepada rakyat dan bangsa Indonesia, bahwa kebahagiaan hidup akan tercapai jika didasarkan atas keselarasan, keserasian dan keseimbangan, baik dalam hubungan 
manusia dengan Tuhan Yang Maha Esa maupun manusia dengan manusia, manusia dengan alam, dan manusia sebagai pribadi, dalam rangka mencapai kemajuan lahir dan kemajuan batin (Agus Rianto:2006). Keselarasan yang tercipta itu adalah wujud dan bukti bahwa pengalaman butir Pancasila sebagai implementasi etika dalam hidup bermasyarakat.

Dalam setiap nilai yang terkandung dalam sila pancasila memiliki etika yang sangat ciri khas dan melekat dengan nilainilai pancasila. Ciri khas itu terlihat jelas karena berkaitan dengan nilai dari setiap pancasila. Pengalaman nilai pancasila yang senantiasa diwujudkan serta diimplentasikan dalam kehidupan berbangsa,bernegara dan bermasyarakat akan menimbulkan berkembangnya etika pancasila. Nila ketuhanan, kemanusian, persatuan, musyawarah serta keadilan menjadi pedoman yang berkontribusi tumbuhnya etika pancasila pada setiap manusia Indonesia.

\section{Peran Guru Dalam Mendorong Pengamalan Butir Pancasila}

Proses perwujudan pengamalan butir pancasila sebagai implementasi etika dalam hidup bermasyarakat tentu banyak pihak yang ikut berkontribusi dalam mewujudkannya. Masyarakat yang menjadi tokoh utama dalam implementasi pengamalan Pancasila merupakan unsur utama. Peserta didik generasi muda yang jadi bibit untuk masa depan adalah unsur utama yang akan terus mewujudkan serta mewariskan pada generasi berikutknya.

Peserta didik merupakan benih dan harapan bagi bangsa perlu dibimbing serta ditanamkan nilai-nilai dan makna Pancasila sedari dini. Menanamkan nilai butir Pancasila dimulai dari lingkungan sekitar, seperti lingkungan rumah dan sekolah. Kita mengetahui bahwa pendidikan adalah sarana utama, usaha sadar untuk menggapai cita-cita. Maka dalam mewujudkan pengamalan implementasi butir Pancasila dilakukan melalui pendidikan.

Pendidikan yang diutamakan dalam menumbuhkan nilai Pancasila dibentuk melalui pendidikan karakater. Karakter yang diharapkan adalah yang senantiasa melekat dan menjiwai nilai- nilai Pancasila, sehingga pengamalan implementasi butir pancasila terus melekat dalam hidup bermasyarakat. Pendidikan karakter pada intinya bertujuan membentuk bangsa yang tangguh, kompetitif, berakhlak mulia, bermoral, bertoleran, bergotong royong, berjiwa patriotik, berkembang dinamis, berorientasi ilmu pengetahuan dan teknologi yang semuanya dijiwai oleh iman dan takwa kepada Tuhan yang Maha Esa berdasarkan Pancasila (Fadil Yudia:2013)

Berdasarkan uraian tersebut, maka dalam pendidikan untuk menanamkan nilai Pancasila kepada generasi muda dalam lingkungan pendidikan yaitu di sekolah, guru adalah kontributor utama dalam menanamkan nilai Pancasila. Guru tidak terlepas dari salah satu perannya yaitu mengajak atau mendidik. Secara umum mendidik bisa artikan sebagai memberikan ilmu, mengajarkan ataupun membina dari yang tidak tahu menjadi mengetahui. Maka disini peran guru sangat penting dalam mengedukasikan nilai Pancasila kepada para generasi muda agar terbentuk dan ternamamkan jiwa nilai dan jiwa Pancasila.

Sebuah karya di tulis oleh Earl V. Pullias dan James D. Young (1968) dalam buku A Teacher Is a Many Things (Suyono \& Hariyanto:2011.Belajar dan Pembelajaran) memaparkan secara sederhana ada empat belas karakteris guru yang unggul. Namun ini hanya mengacu pada tiga karakteristik yang mendorong dalam kontribusi pengamalan butir Pancasila. Karakteristik unggul yang dimaksud ini dikontribusikan dengan peran guru dalam menanamakan serta mendorong nilai Pancasila dalam 
pengamalannya.

Berikut diantaranya (1) guru sebagai guru: sebagai guru, kontribusi dalam pengamalan butir Pancasila bermakna bahwa guru itu mengajarkan pengetahuan tentang Pancasila.(2) guru sebagai teladan: bisa mencontohkan tindakan, perilaku yang mencerminkan pengamalan dari setiap butir Pancasila sehingga para peserta didik meneladani atas apa yang menjadi tauladan mereka (3) guru sebagai penasihat : menasehati para peserta didik bahwa sangat pentingnya kita sebagai warga negara hidup bermasyarakat berpedoman pada butir Pancasila (Suyono \& Hariyanto:2011). Maka ini memungkinkan jadi acuan untuk mendorong dalam peran guru mewujudkan pengamalan implementasi Pancasila dalam hidip bermasyarakat pada peserta didik.

Dalam pendidikan suatu bangsa akan secara otomatis mengikuti ideologi bangsanya. Artinya bangsa Indonesia secara otomatis mengikuti ajaran dari ideologi bangsa yaitu Pancasila. Oleh karena itu sistem pendidikan nasional Indonesia dijiwai, didasari, dan mencerminkan identitas Pancasila (Agus Suntono:2015). Maka karena hal itu dapat sangat mendorong dan mempermudahkan dalam penanaman dan penjiwaan kepada generasi muda yang akan mendatang.

\section{KESIMPULAN}

Dari penjabaran diatas dapat disimpilkan bahwa Pancasila dan etika merupakan dua hal yang tidak dapat dipisahkan karena merupakan suatu sistem yang membentuk satu kesatuan yang utuh, saling berkaitan serta berkesinambungan satu dengan yang lain yang dijadikan pedoman dalam kehidupan bermasyarakat, berbangsa dan bernegara. Implementasi Pancasila sebagai sistem etika dapat terwujud apabila pemerintah dan masyarakat dapat menerapkan nilainilai yang ada dalam pancasila dengan mengedepankan prinsip keseimbangan antara hak dan kewajiban. Pancasila hakikatnya menjadi dasar dan pedoman bagi Bangsa Indonesia dalam bersikap dan bertingkah laku sehingga nantinya akan terwujud masyarakat cerdas, berbudi luhur serta adil dan makmur sesuai dengan tujuan negara itu sendiri. Pada setiap sendi-sendi kehidupan masyarakat, harus senatiasa menerapkan

nilai-nilai pancasila baik dalam kehidupan sehari-hari maupun dalam kehidupan berbangsa dan bernegara sehingga terwujud perilaku etika yang menjunjung tinggi nilai moralitas sebagai perwujudan dari ciri dan kepribadian dari Bangsa Indonesia. Penulis sangat mengharapkan kritik serta saran dari khalayak yang telah membaca artikel ini agar penulis senantiasa terus mengembangkan dan meningkatkan lagi terkait isi, baik dari wawasan atau hal yang menjadi pendorong untuk senantiasa menulis dan menambah pengetahuan tentang apapun. Adapun hal lain yang ingin diungkupan penulis bahwa kita sebagai calon pendidik dimasa yang akan datang harus senantiasa melekatkan nilai-nilai, makna, serta pengetahuan tentang pancasila pada generasi-generasi penerus agar menjadi generasi yang sangat menjiwai Pancasila

\section{DAFTAR PUSTAKA}

Achmad Muchji,dkk(2007). Pendidikan Pancasila. Penerbit Gunadarma: Jakarta

Agus Rianto (2006). Pengamalan/Aplikasi Nilai-nila Pancasila Dalam Aspek Pengelolaan Lingkungan Hidup. Yustia. No 69. 1-6.pdf

Agus Suntono (2015). Meneguhkan Pancasila Sebagai Filasafat Pendidikan Nasional. Jurnal Ilmiah CIVIS, 5 (1).666-67. Pdf 
Agustinus (2015). Pancasila dan Multikulturalisme Indonesia. Studia Philosophica et Theologica.15(2).109-126.pdf

Asep Sulaiman(2015). Pendidikan Pancasila dan Kewarganegaraan. CV Arfino Raya: Bandung

Dewantara, J. A., Hermawan, Y., Yunus, D., Prasetiyo, W. H., Efriani, Arifiyanti, F., \& Nurgiansah, T. H. (2021). Anti-Corruption Education as an Effort to Form Students With Character Humanist and Law-Compliant. Jurnal Civics: Media Kajian Kewarganegaraan, 18(1), $70-$ 81.

Dewantara, J. A., \& Nurgiansah, T. H. (2021). Building Tolerance Attitudes Of PPKN Students Through Multicultural Education Courses. Jurnal Etika Demokrasi, 6(1), 103-115.

Dewantara, J. A., Nurgiansah, T. H., \& Rachman, F. (2021). Mengatasi Pelanggaran Hak Asasi Manusia dengan Model Sekolah Ramah HAM (SR-HAM). Edukatif: Jurnal Ilmu Pendidikan, 3(2), 261-269.

Fadil Yudia,dkk(2013). Peran Guru Pendidikan Pancasila dan Kewarganegaraan dalam Upaya Pembentukan Karakter Peserta Didik. Jurnal PPKN Online. 1(2). 1-15.pdf

Iriyanto, dkk (2007). Buku Ajar Pendidikan Pancasila. Universitas Diponegoro: Semarang

Kaelan (2013). Negara Kebangsaan Pancasila Kultural, Historis, Filosofis, Yuridis dan Aktualisasinya. Paradigma:Yogyakarta

Koesnadi Hardjasoemantri (2000). Hukum Tata Lingkungan. Yogyakarta: Gadjah Mada University Press

Nurgiansah, T. H. (2021a). Pendidikan Pancasila. In Solok: CV Mitra Cendekia Media.

Nurgiansah, T. H. (2021b). The Role of Citizenship Education in Building Bantul Community Political Participation in The Pandemic Covid 19. Prosiding Seminar Nasional Pendidikan Dan Kewirausahaan, 4(1), 1-4.

Nurgiansah, T. H., \& Widyastuti, T. M. (2020). Membangun Kesadaran Hukum Mahasiswa PPKn UPY Dalam Berlalu Lintas. Civic Edu: Jurnal Pendidikan Kewarganegaraan Universitas Pasundan, 2(2), 97-102. https://doi.org/10.1017/CB09781107415324.004

Sri Rahayu (2018). Pancasila Sebagai Sistem Etika. Jurnal Voice Of Midwifery. 8(1).760-768.pdf Suyono \& Hariyanto,(2011).Belajar dan Pembelajaran Teori dan Konsep Dasar. Bandung: PT Remaja Rosdakarya 